\title{
Lactate and Pyruvate Metabolism in the Exercising Ischemic Limb *
}

\author{
B. L. Pentecost, † J. A. Reid, and D. Reid \\ (From the Medical Research Council Cardiovascular Research Group, Department of Medicine, \\ Postgraduate Medical School, London, England)
}

It has long been appreciated that contraction of skeletal muscle results in the production of lactic acid. Fletcher and Hopkins (1) demonstrated that stimulation and contraction of an isolated muscle preparation led to the accumulation of lactic acid and eventual fatigue. This process was accelerated by anaerobic conditions and delayed in an oxygen-enriched atmosphere. Much of the lactate derived from muscle glycogen appeared to be resynthesized to glycogen during the recovery period (2). In man total body oxygen uptake after exercise was found to be inadequate to permit oxidation of all the lactate formed during the exercise period, implying that a similar resynthesis was occurring (3). There remains some controversy over the site of glycogen resynthesis, but attention has been drawn to the important part played by the liver during muscular activity (4), lactate being taken up by the liver and glucose released. The ability of mammalian skeletal muscle to resynthesize glycogen from lactate is less certain. More recently the expected increase in lactate production by the limb during exercise has been demonstrated by measuring arteriovenous differences in lactate concentration across the limb before and during the period of activity (5-7). Possibly because of difficulties encountered in measurement of blood flow through exercising limbs, the time course of lactate has not been determined during exercise in man. It might be expected that, since in a limb with major arterial occlusion oxygen consumption is continued into the recovery period (8), there would be evidence of sustained lactate production. This study was designed to investigate the production of lactate during and after exercise by measuring

\footnotetext{
* Submitted for publication September 29, 1965; accepted February 17, 1966.

† Address requests for reprints to Dr. B. L. Pentecost, Dept. of Medicine, Queen Elizabeth Hospital, Edgbaston, Birmingham 15, England.
}

limb blood flow and arteriovenous difference of lactic acid in a group of patients with occlusive arterial disease. Huckabee (9) has shown that a rising lactate concentration is not specifically indicative of anaerobic conditions and that it is necessary to take account of the concentration of pyruvate in the blood if a true indication of the anaerobic state of the tissues is sought. Simultaneous observations have, therefore, been made on pyruvate metabolism.

\section{Methods}

Ten male subjects, average age 58 (range 51 to 68 ), were studied. Nine subjects had bilateral occlusive arterial disease of the lower limbs. All experienced the symptom of intermittent claudication, pain in the calf, thigh, or buttocks being experienced when walking between 25 and 100 yards at a slow pace. No evidence of cardiopulmonary disease was detected in any patient by clinical examination, chest $\mathrm{X}$ ray, or electrocardiogram. In these nine men, arteriograms revealed a complete occlusion of one or more main arteries in both limbs. In six patients the artery affected was the superficial femoral or one of its branches, but in subjects J.R., J.Mc., and H.L. the common iliac vessel was obstructed. One 51-year-old subject, T.C., had normal vasculature on arteriography, and his leg pain was due to mild degenerative arthritis of the hip.

The subjects were fasted overnight and mildly sedated with $75 \mathrm{mg}$ pethidine and $25 \mathrm{mg}$ phenergan administered intramuscularly 1 hour before the study. The procedure was carried out at a room temperature of 21 to $23^{\circ} \mathrm{C}$, with the patients wearing loosely fitting clothing. The brachial artery was catheterized by the Seldinger technique (10). PE 60 polythene tubing (i.d. $0.76 \mathrm{~mm}$ ) was left indwelling for blood sampling. Catheterization was performed from an antecubital vein with a specially adapted no. 9 U.S. double lumen cardiac catheter with a three-hole spray tip and a sampling orifice $15 \mathrm{~mm}$ proximal to the tip. The tip of the catheter was advanced under fluoroscopic control into the external iliac vein of the more severely affected leg, 4 to $6 \mathrm{~cm}$ distal to its junction with the internal iliac vein. In each instance the catheter position was confirmed by venous angiography. Heparin (60 mg) was administered intravenously to prevent clotting of the sampling orifice. 
TABLE I

Blood flow $(\dot{Q})$ and arterial $(A)$ and venous $(V)$ lactate

\begin{tabular}{|c|c|c|c|c|c|c|c|c|c|c|c|c|c|c|c|c|}
\hline \multirow{3}{*}{$\begin{array}{c}\text { Subject } \\
\text { Work load }\end{array}$} & & & & & \multicolumn{6}{|c|}{ Exercise } & \multicolumn{6}{|c|}{ Recovery } \\
\hline & & \multicolumn{3}{|c|}{ Rest } & \multicolumn{3}{|c|}{2 minutes } & \multicolumn{3}{|c|}{4 minutes } & \multicolumn{3}{|c|}{2 minutes } & \multicolumn{3}{|c|}{5 minutes } \\
\hline & & Q & La & Py & $\dot{Q}$ & $\mathrm{La}$ & $\overline{P y}$ & $\dot{Q}$ & $\mathrm{La}$ & Py & $\dot{Q}$ & $\mathrm{La}$ & $\overline{P y}$ & $\dot{Q}$ & $\mathrm{La}$ & $\overline{P y}$ \\
\hline \multicolumn{2}{|l|}{$k g-m / \min$} & $m i /$ & \multicolumn{2}{|c|}{ mmoles $/ L$} & $\mathrm{ml} / \mathrm{min}$ & \multicolumn{2}{|c|}{ mmoles $/ L$} & \multirow{3}{*}{\multicolumn{3}{|c|}{$\begin{array}{c}m l / \min \text { mmoles } / L \\
\text { Exercise discon- } \\
\text { tinued at } 3 \mathrm{~min}\end{array}$}} & \multirow[t]{2}{*}{$m l / \min$} & \multicolumn{2}{|c|}{ mmoles $/ L$} & $m l / m i n$ & \multicolumn{2}{|c|}{ mmoles $/ L$} \\
\hline \multirow{2}{*}{ J.R. } & A & & 0.60 & 0.030 & & 1.82 & 0.076 & & & & & 3.92 & 0.136 & & 3.68 & 0.180 \\
\hline & V & 390 & 0.80 & 0.046 & 610 & 4.62 & 0.200 & & & & 1,590 & 6.70 & 0.143 & 2,620 & 6.37 & 0.197 \\
\hline$\underset{150}{\text { J.Mc. }}$ & $\mathrm{A}$ & 210 & $\begin{array}{l}0.63 \\
0.88\end{array}$ & $\begin{array}{l}0.022 \\
0.053\end{array}$ & 370 & $\begin{array}{l}1.84 \\
3.54\end{array}$ & $\begin{array}{l}0.102 \\
0.220\end{array}$ & \multicolumn{3}{|c|}{$\begin{array}{l}\text { Exercise discon- } \\
\text { tinued at } 3 \mathrm{~min}\end{array}$} & 400 & $\begin{array}{l}2.85 \\
6.08\end{array}$ & $\begin{array}{l}0.145 \\
0.138\end{array}$ & 410 & $\begin{array}{l}3.54 \\
5.15\end{array}$ & $\begin{array}{l}0.227 \\
0.194\end{array}$ \\
\hline $\begin{array}{l}\text { H.L. } \\
150\end{array}$ & $\mathrm{~A}$ & 360 & $\begin{array}{l}0.83 \\
0.90\end{array}$ & $\begin{array}{l}0.073 \\
0.068\end{array}$ & 930 & $\begin{array}{l}1.34 \\
2.62\end{array}$ & $\begin{array}{l}0.100 \\
0.177\end{array}$ & 900 & $\begin{array}{l}2.50 \\
3.97\end{array}$ & $\begin{array}{l}0.108 \\
0.159\end{array}$ & 500 & $\begin{array}{l}3.27 \\
7.06\end{array}$ & $\begin{array}{l}0.165 \\
0.161\end{array}$ & 610 & $\begin{array}{l}2.97 \\
5.59\end{array}$ & $\begin{array}{l}0.211 \\
0.255\end{array}$ \\
\hline $\begin{array}{l}\text { D.Le. } \\
150\end{array}$ & $\begin{array}{l}\mathrm{A} \\
\mathrm{V}\end{array}$ & 230 & $\begin{array}{l}0.38 \\
0.40\end{array}$ & $\begin{array}{l}0.023 \\
0.027\end{array}$ & 750 & $\begin{array}{l}0.98 \\
1.48\end{array}$ & $\begin{array}{l}0.057 \\
0.053\end{array}$ & 810 & $\begin{array}{l}2.05 \\
3.73\end{array}$ & $\begin{array}{l}0.083 \\
0.117\end{array}$ & 900 & $\begin{array}{l}2.44 \\
3.96\end{array}$ & $\begin{array}{l}0.109 \\
0.111\end{array}$ & 430 & $\begin{array}{l}1.88 \\
2.93\end{array}$ & $\begin{array}{l}0.115 \\
0.110\end{array}$ \\
\hline $\begin{array}{l}\text { A.D. } \\
150\end{array}$ & $\stackrel{\mathbf{A}}{\mathbf{V}}$ & 190 & $\begin{array}{l}0.69 \\
0.94\end{array}$ & $\begin{array}{l}0.036 \\
0.042\end{array}$ & 710 & $\begin{array}{l}1.35 \\
1.89\end{array}$ & $\begin{array}{l}0.095 \\
0.106\end{array}$ & 920 & $\begin{array}{l}1.87 \\
2.24\end{array}$ & $\begin{array}{l}0.120 \\
0.123\end{array}$ & 630 & $\begin{array}{l}1.73 \\
1.87\end{array}$ & $\begin{array}{l}0.137 \\
0.143\end{array}$ & 220 & $\begin{array}{l}1.72 \\
1.79\end{array}$ & $\begin{array}{l}0.132 \\
0.128\end{array}$ \\
\hline L.O. & $\stackrel{\mathbf{A}}{\mathrm{V}}$ & 290 & $\begin{array}{l}0.91 \\
1.01\end{array}$ & $\begin{array}{l}0.036 \\
0.058\end{array}$ & 700 & $\begin{array}{l}1.13 \\
2.06\end{array}$ & $\begin{array}{l}0.053 \\
0.099\end{array}$ & 850 & $\begin{array}{l}1.58 \\
2.38\end{array}$ & $\begin{array}{l}0.069 \\
0.107\end{array}$ & 340 & $\begin{array}{l}1.40 \\
2.95\end{array}$ & $\begin{array}{l}0.104 \\
0.135\end{array}$ & 350 & $\begin{array}{l}1.54 \\
2.10\end{array}$ & $\begin{array}{l}0.106 \\
0.133\end{array}$ \\
\hline$\underset{50}{\text { D.R. }}$ & $\stackrel{\mathbf{A}}{\mathbf{V}}$ & 420 & $\begin{array}{l}0.87 \\
1.08\end{array}$ & $\begin{array}{l}0.047 \\
0.052\end{array}$ & 1,700 & $\begin{array}{l}1.09 \\
1.38\end{array}$ & $\begin{array}{l}0.057 \\
0.063\end{array}$ & 2,350 & $\begin{array}{l}1.58 \\
2.46\end{array}$ & $\begin{array}{l}0.077 \\
0.076\end{array}$ & 1,010 & $\begin{array}{l}1.95 \\
2.54\end{array}$ & $\begin{array}{l}0.124 \\
0.094\end{array}$ & 570 & $\begin{array}{l}1.86 \\
2.45\end{array}$ & $\begin{array}{l}0.136 \\
0.103\end{array}$ \\
\hline$\underset{150}{\text { H.L.C. }}$ & $\mathbf{A}$ & 160 & $\begin{array}{l}0.64 \\
0.80\end{array}$ & $\begin{array}{l}0.056 \\
0.065\end{array}$ & 1,490 & $\begin{array}{l}1.73 \\
2.97\end{array}$ & $\begin{array}{l}0.065 \\
0.089\end{array}$ & 1,670 & $\begin{array}{l}2.44 \\
3.39\end{array}$ & $\begin{array}{l}0.091 \\
0.105\end{array}$ & 680 & $\begin{array}{l}2.57 \\
3.41\end{array}$ & $\begin{array}{l}0.155 \\
0.194\end{array}$ & 510 & $\begin{array}{l}2.16 \\
2.87\end{array}$ & $\begin{array}{l}0.163 \\
0.163\end{array}$ \\
\hline $\begin{array}{l}\text { E.J. } \\
150\end{array}$ & $\stackrel{\mathrm{A}}{\mathrm{V}}$ & 240 & $\begin{array}{l}0.62 \\
0.88\end{array}$ & $\begin{array}{l}0.037 \\
0.052\end{array}$ & 1,670 & $\begin{array}{l}1.52 \\
2.58\end{array}$ & $\begin{array}{l}0.088 \\
0.147\end{array}$ & 2,150 & $\begin{array}{l}2.57 \\
3.70\end{array}$ & $\begin{array}{l}0.108 \\
0.140\end{array}$ & 1,490 & $\begin{array}{l}2.66 \\
3.90\end{array}$ & $\begin{array}{l}0.217 \\
0.266\end{array}$ & 860 & $\begin{array}{l}2.47 \\
2.92\end{array}$ & $\begin{array}{l}0.213 \\
0.252\end{array}$ \\
\hline $\begin{array}{l}\text { T.C. } \\
150\end{array}$ & $\stackrel{\mathbf{A}}{\mathbf{V}}$ & 440 & $\begin{array}{l}0.43 \\
0.62\end{array}$ & $\begin{array}{l}0.030 \\
0.030\end{array}$ & 1,300 & $\begin{array}{l}1.03 \\
1.42\end{array}$ & $\begin{array}{l}0.059 \\
0.077\end{array}$ & 2,000 & $\begin{array}{l}1.13 \\
1.86\end{array}$ & $\begin{array}{l}0.063 \\
0.085\end{array}$ & 710 & $\begin{array}{l}0.98 \\
1.21\end{array}$ & $\begin{array}{l}0.068 \\
0.098\end{array}$ & 640 & $\begin{array}{l}0.81 \\
1.02\end{array}$ & $\begin{array}{l}0.059 \\
0.066\end{array}$ \\
\hline
\end{tabular}

The subjects were allowed a further 30 minutes' rest after positioning of the catheters before observations were begun.

External iliac venous flow measurement was made utilizing a continuous injection dilution technique (11) that has been further verified in animal experiments (12) and used extensively in man $(8,13,14)$. The indicator, albumin- ${ }^{181} \mathrm{I}$ diluted in physiological saline, was injected through the spray tip at a constant rate of approximately $130 \mathrm{ml}$ per minute. In vessels $1 \mathrm{~cm}$ in diameter this gives uniform mixing at flow rates of up to $2.7 \mathrm{~L}$ per minute (13). Injection of indicator has been demonstrated not to diminish the venous return or to produce changes in local venous pressure. Two or three measurements were made at rest over a 15-minute period, and single estimations were made during the second and fourth minutes of exercise and the second, fifth, tenth, fifteenth, twenty-fifth, and fiftieth minutes during the recovery period.

A bicycle ergometer, set at a constant load, was operated by the supine subject during the exercise period, which lasted 4 minutes, except for subjects J.R. and J.Mc., who were prevented from completing the exercise by severe leg pain during exercise. The rate of work performed was $150 \mathrm{~kg}-\mathrm{m}$ per minute in all but two subjects, who could achieve only $50 \mathrm{~kg}-\mathrm{m}$ per minute. External iliac venous blood samples for oxygen analysis were collected 20 seconds before flow measurements. Arterial blood samples were obtained at rest, during exercise, and in the recovery period. Blood oxygen saturation analyses were performed in duplicate on the Kipp hemoreflector oximeter.

Arterial and external iliac venous blood samples for pyruvic and lactic acid determinations were collected simultaneously 20 to 45 seconds after each blood flow measurement. The blood was immediately transferred from the collecting syringe to a chilled, weighed tube containing $10 \%$ trichloroacetic acid in $0.5 \mathrm{~N}$ hydrochloric acid packed about with ice until centrifugation at the end of the study. Trichloroacetic acid was used in preference to perchloric acid because the former has been demonstrated to yield $97 \%$ recovery of pyruvate standards from whole blood, whereas perchloric acid, although efficient in the case of plasma, yielded only $60 \%$ from whole blood (15), possibly due to failure to inhibit lactic dehydrogenase in the red cells. Some preliminary experiments in this laboratory confirmed these observations. Lithium pyruvate standards were used; comparison with a sodium pyruvate standard revealed no difference between the two. The pyruvate and lactic acid concentration in the supernatant was determined in duplicate by a modification of the enzymatic spectrophotometric method ${ }^{1}$ (15). Recovery of lactic acid added to blood supernatant averaged $96 \%$ with linearity of recovery from 0.5 mmole per $\mathrm{L}$ up to 8 mmoles per $\mathrm{L}$. Recovery of pyruvic acid averaged $106 \%$ with linearity of recovery from 0.05 mmole per $\mathrm{L}$ to 0.40 mmole per L. The mean difference between duplicate lactic acid determinations (181 pairs) was 0.049 mmole per L (SD $0.0813)$. The mean difference between pyruvic acid duplicate determinations $(n=171$ pairs $)$ was 0.003 mmole per L). The lactic acid values were calculated as millimoles per liter of blood water (measured by desiccation). Arteriovenous differences were then multiplied by the corresponding flow measurement to calculate lactate and

\footnotetext{
1 Boehringer and Sons, Mannheim, Germany.
} 
TABLE I

(La) and Pyruvate (Py) concentrations during the study

\begin{tabular}{|c|c|c|c|c|c|c|c|c|c|c|c|c|c|c|}
\hline \multicolumn{15}{|c|}{ Recovery } \\
\hline \multicolumn{3}{|c|}{10 minutes } & \multicolumn{3}{|c|}{15 minutes } & \multicolumn{3}{|c|}{25 minutes } & \multicolumn{3}{|c|}{35 minutes } & \multicolumn{3}{|c|}{50 minutes } \\
\hline$\grave{Q}$ & $\mathrm{La}$ & $\overline{P y}$ & $\dot{Q}$ & $\mathrm{La}$ & $\mathbf{P y}$ & $\dot{\mathbf{Q}}$ & $\mathrm{La}$ & Py & $\mathbf{Q}$ & $\mathrm{La}$ & Py & $\dot{\mathbf{Q}}$ & $\mathrm{La}$ & Py \\
\hline \multirow[t]{2}{*}{$m l / m i n$} & \multicolumn{2}{|c|}{ mmoles $/ L$} & $\operatorname{ml} / \min$ & \multicolumn{2}{|c|}{ mmoles $/ L$} & $m l / m i n$ & \multicolumn{2}{|c|}{ mmoles $/ L$} & $m l / m i n$ & \multicolumn{2}{|c|}{ mmoles $/ L$} & $m l / m i n$ & \multicolumn{2}{|c|}{ mmoles $/ L$} \\
\hline & 3.48 & 0.186 & & 2.86 & 0.165 & & 1.96 & 0.128 & & 1.43 & 0.090 & & 0.88 & 0.060 \\
\hline 2,620 & 5.39 & 0.203 & 2,160 & 4.06 & 0.173 & 810 & 2.70 & 0.134 & 810 & 1.78 & 0.110 & 380 & 1.30 & 0.069 \\
\hline 440 & $\begin{array}{l}2.96 \\
4.11\end{array}$ & $\begin{array}{l}0.236 \\
0.250\end{array}$ & 370 & $\begin{array}{l}2.11 \\
2.96\end{array}$ & $\begin{array}{l}0.209 \\
0.185\end{array}$ & 230 & $\begin{array}{l}1.44 \\
1.77\end{array}$ & $\begin{array}{l}0.150 \\
0.125\end{array}$ & 230 & $\begin{array}{l}1.03 \\
1.35\end{array}$ & $\begin{array}{l}0.119 \\
0.104\end{array}$ & 240 & $\begin{array}{l}1.10 \\
1.03\end{array}$ & $\begin{array}{l}0.148 \\
0.099\end{array}$ \\
\hline 530 & $\begin{array}{l}2.42 \\
4.28\end{array}$ & $\begin{array}{l}0.167 \\
0.231\end{array}$ & 490 & $\begin{array}{l}2.15 \\
3.64\end{array}$ & $\begin{array}{l}0.150 \\
0.168\end{array}$ & 500 & $\begin{array}{l}1.33 \\
2.01\end{array}$ & $\begin{array}{l}0.121 \\
0.116\end{array}$ & 360 & $\begin{array}{l}0.95 \\
1.36\end{array}$ & $\begin{array}{l}0.092 \\
0.101\end{array}$ & 310 & $\begin{array}{l}0.60 \\
0.98\end{array}$ & $\begin{array}{l}0.077 \\
0.083\end{array}$ \\
\hline 160 & $\begin{array}{l}1.43 \\
1.94\end{array}$ & $\begin{array}{l}0.093 \\
0.089\end{array}$ & 150 & $\begin{array}{l}1.08 \\
1.56\end{array}$ & $\begin{array}{l}0.078 \\
0.067\end{array}$ & 110 & $\begin{array}{l}0.72 \\
0.90\end{array}$ & $\begin{array}{l}0.058 \\
0.049\end{array}$ & 150 & $\begin{array}{l}0.65 \\
0.62\end{array}$ & $\begin{array}{l}0.043 \\
0.040\end{array}$ & 180 & $\begin{array}{l}0.54 \\
0.51\end{array}$ & $\begin{array}{l}0.046 \\
0.041\end{array}$ \\
\hline 290 & $\begin{array}{l}1.46 \\
1.69\end{array}$ & $\begin{array}{l}0.116 \\
0.106\end{array}$ & & & & 200 & $\begin{array}{l}1.52 \\
1.53\end{array}$ & $\begin{array}{l}0.098 \\
0.092\end{array}$ & 140 & $\begin{array}{l}1.23 \\
1.44\end{array}$ & $\begin{array}{l}0.094 \\
0.074\end{array}$ & & & \\
\hline 530 & $\begin{array}{l}1.47 \\
1.87\end{array}$ & $\begin{array}{l}0.089 \\
0.113\end{array}$ & 460 & $\begin{array}{l}1.31 \\
1.69\end{array}$ & $\begin{array}{l}0.082 \\
0.094\end{array}$ & 350 & $\begin{array}{l}1.24 \\
1.29\end{array}$ & $\begin{array}{l}0.081 \\
0.077\end{array}$ & & & & 310 & $\begin{array}{l}0.92 \\
1.09\end{array}$ & $\begin{array}{l}0.080 \\
0.070\end{array}$ \\
\hline 460 & $\begin{array}{l}1.54 \\
2.09\end{array}$ & $\begin{array}{l}0.112 \\
0.085\end{array}$ & 480 & $\begin{array}{l}1.29 \\
1.67\end{array}$ & $\begin{array}{l}0.100 \\
0.082\end{array}$ & 400 & $\begin{array}{l}1.28 \\
1.44\end{array}$ & $\begin{array}{l}0.078 \\
0.074\end{array}$ & & & & 420 & $\begin{array}{l}0.90 \\
1.11\end{array}$ & $\begin{array}{l}0.064 \\
0.054\end{array}$ \\
\hline 240 & $\begin{array}{l}1.68 \\
1.74\end{array}$ & $\begin{array}{l}0.138 \\
0.102\end{array}$ & 210 & $\begin{array}{l}1.25 \\
1.57\end{array}$ & $\begin{array}{l}0.110 \\
0.104\end{array}$ & 190 & $\begin{array}{l}1.00 \\
1.12\end{array}$ & $\begin{array}{l}0.088 \\
0.090\end{array}$ & 170 & $\begin{array}{l}0.79 \\
1.03\end{array}$ & $\begin{array}{l}0.061 \\
0.064\end{array}$ & 210 & $\begin{array}{l}0.63 \\
0.80\end{array}$ & $\begin{array}{l}0.057 \\
0.064\end{array}$ \\
\hline & & & 310 & $\begin{array}{l}1.77 \\
2.28\end{array}$ & $\begin{array}{l}0.172 \\
0.136\end{array}$ & 250 & $\begin{array}{l}1.32 \\
1.65\end{array}$ & $\begin{array}{l}0.125 \\
0.143\end{array}$ & 200 & $\begin{array}{l}1.18 \\
1.40\end{array}$ & $\begin{array}{l}0.131 \\
0.102\end{array}$ & & & \\
\hline 530 & $\begin{array}{l}0.59 \\
0.78\end{array}$ & $\begin{array}{l}0.048 \\
0.047\end{array}$ & & $\begin{array}{l}0.44 \\
0.71\end{array}$ & $\begin{array}{l}0.044 \\
0.049\end{array}$ & 450 & $\begin{array}{l}0.46 \\
0.53\end{array}$ & $\begin{array}{l}0.041 \\
0.048\end{array}$ & 440 & $\begin{array}{l}0.35 \\
0.45\end{array}$ & $\begin{array}{l}0.047 \\
0.047\end{array}$ & 340 & $\begin{array}{l}0.32 \\
0.40\end{array}$ & $\begin{array}{l}0.034 \\
0.039\end{array}$ \\
\hline
\end{tabular}

pyruvate production or oxygen consumption of the limb. Excess lactate production by the leg was calculated with the instantaneous arteriovenous lactate-pyruvate ratio after the manner of Huckabee (1959) (16).

\section{Results}

Blood flow and lactate and pyruvate concentrations are shown in Table I and the calculated oxygen consumption and lactate and pyruvate release in Table II. Excess lactate production and the local oxygen debt are also tabulated in Table II.

Blood flow. Resting lower limb blood flow ranged from 160 to $440 \mathrm{ml}$ per minute (mean 290 $\mathrm{ml}$ per minute). On exercise the blood flow always increased at the first estimation made at 2 minutes, and a similar value was usually recorded at 4 minutes. Two blood flow patterns emerged. In one there was a brisk rise in flow during activity to several times the resting value; on cessation of exercise the blood flow fell to near resting values in a short period of time (Figures 1 and 2). This response was seen in patients T.C., H.L.C., A.D., and D.R. The second pattern comprised a moderate increase in flow during exercise that was either continued long into the recovery period or actually increased in the latter period. This response is well illustrated by subjects J.R., J.Mc., D.Le., and H.L. (Figures 3 and 4).
Oxygen consumption. At rest the lower limb consumed oxygen at from 7 to $21 \mathrm{ml}$ per minute (mean $13.7 \mathrm{ml}$ per minute). During exercise oxygen consumption always increased above resting values, the uptake being mainly during the active period in those patients with a brisk flow response, but was greatly prolonged into the recovery period in patients with a protracted postexercise hyperemia.

Lactate and excess lactate release. The mean concentration of lactate in arterial blood at rest

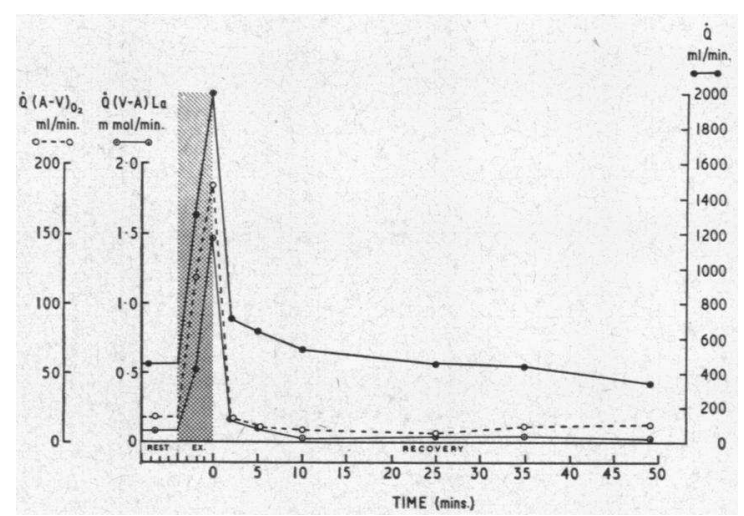

FIG. 1. BLOOD FLOW (Q), OXYGEN CONSUMPTION $\left[\dot{Q}(\mathrm{~A}-\mathrm{V}) \mathrm{O}_{2}\right]$, and LACTATE RELEASE [Q $\left.(\mathrm{V}-\mathrm{A}) \mathrm{LA}\right]$ IN THE LOWER LIMB BEFORE, DURING, AND AFTER EXERCISE IN_NORMAL:SUBJECT T.C. 
was 0.66 mmole per $\mathrm{L}(\mathrm{SD} 0.16, \mathrm{n}=10)$ and in the venous blood 0.83 mmole per L (SD 0.18). In all patients there was a negative arteriovenous difference at rest (average 0.17 mmole per L) that was significant ( $\mathrm{SE} 0.075, \mathrm{p} 0.025$ ), indicating production of small quantities of lactate by the inactive limb. During exercise the quantity of lactate leaving the leg increased and in the recovery period returned towards resting values. In those subjects showing a prolonged hyperemia and oxygen consumption into the recovery period, the washout of lactate was similarly pro- longed (Figures 3 and 4). This extended production of lactate was observed only in those subjects who failed to reach a peak blood flow of 900 $\mathrm{ml}$ per minute. In the later stages of the 50-minute recovery period the local blood flow and lactate release always returned to resting values, although the arterial and venous concentrations of lactate were still elevated. At no time was there apparent uptake of lactate by the recovering limb even in the presence of a raised arterial concentration.

Total lactate and excess lactate production were

TABLE II

Oxygen consumption $\dot{Q}(A-V) O_{2}$, lactate release $\dot{Q}(V-A)$ La, and pyruvate release $\dot{Q}(V-A) P y$ during the study period

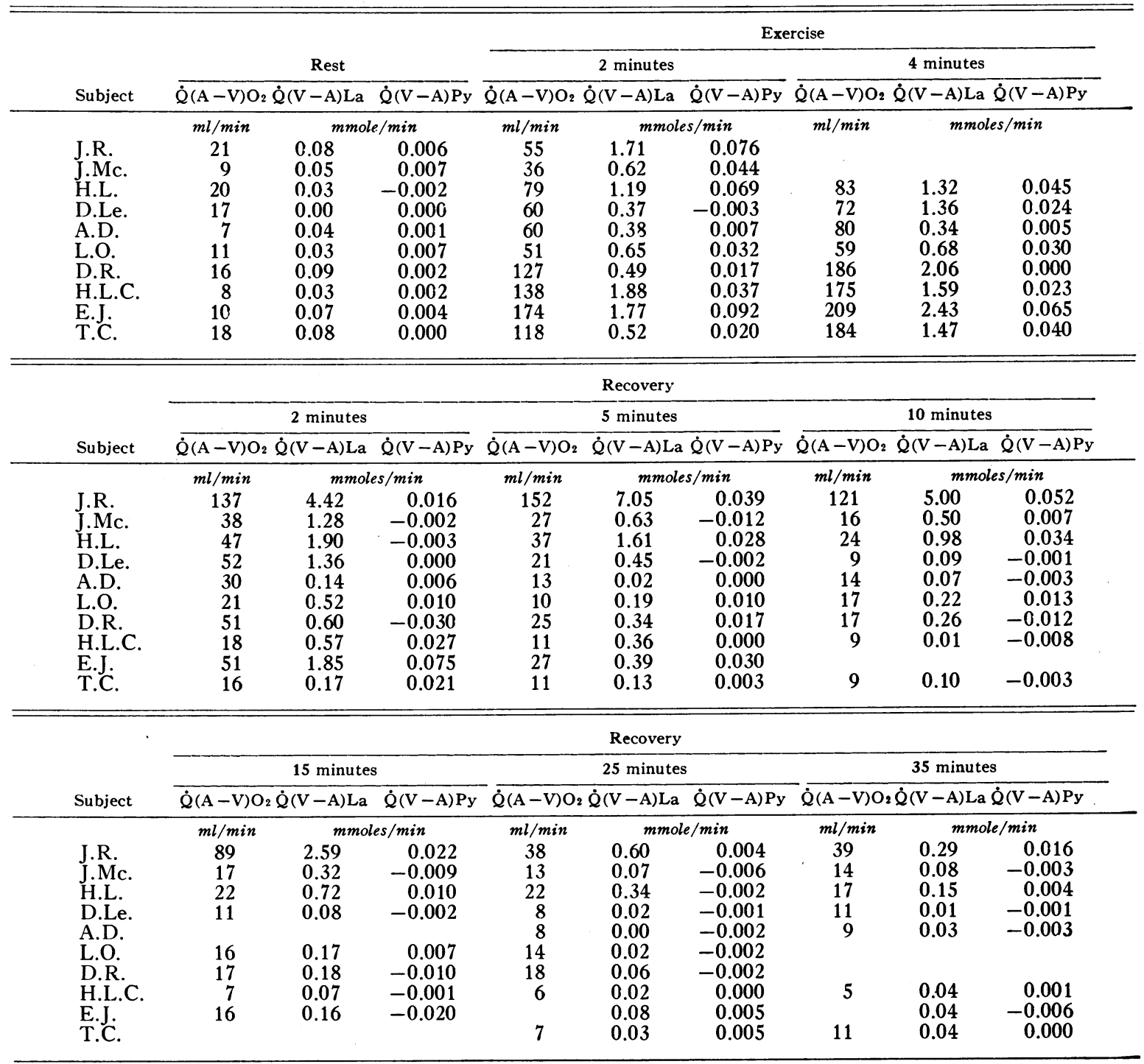




\begin{tabular}{|c|c|c|c|}
\hline \multirow[b]{3}{*}{ Subject } & \multicolumn{3}{|c|}{ Recovery } \\
\hline & \multicolumn{3}{|c|}{50 minutes } \\
\hline & \multicolumn{3}{|c|}{$\overline{Q(A-V) O_{2} \dot{Q}(V-A) L a \quad \dot{Q}(V-A) P y}$} \\
\hline \multirow{4}{*}{$\begin{array}{l}\text { J.R. } \\
\text { J.Mc. } \\
\text { H.L. } \\
\text { D.Le. } \\
\text { A.D. } \\
\text { L.O. } \\
\text { D.R. } \\
\text { H.L.C. } \\
\text { E.J. } \\
\text { T.C. }\end{array}$} & \multicolumn{3}{|c|}{$\mathrm{ml} / \mathrm{min} \quad \mathrm{mmole} / \min$} \\
\hline & $\begin{array}{l}16 \\
10 \\
20 \\
15\end{array}$ & $\begin{array}{r}0.16 \\
-0.02 \\
0.11 \\
0.01\end{array}$ & $\begin{array}{r}0.004 \\
-0.012 \\
0.003 \\
-0.001\end{array}$ \\
\hline & $\begin{array}{r}13 \\
17 \\
7\end{array}$ & $\begin{array}{l}0.05 \\
0.08 \\
0.03\end{array}$ & $\begin{array}{r}-0.003 \\
-0.004 \\
0.002\end{array}$ \\
\hline & 13 & 0.03 & 0.002 \\
\hline
\end{tabular}

estimated by calculating the area under timelactate production curves constructed from the data in Tables II and III. Table III shows that among patients with severe occlusive arterial disease, as suggested by failure to complete the exercise or a peak lower limb blood flow of less than $1 \mathrm{~L}$ per minute, the excess lactate produced accounts for most of the total lactate production. In contrast, in the lower half of the Table, which contains the patients with higher peak flows and the normal subject T.C., excess lactate accounts for a smaller fraction of total lactate production. Local oxygen debt, i.e., the volume of oxygen consumed by the limb during the recovery period in excess of resting requirements, was directly related to the total excess lactate production over the same period $(r=+0.97)$ when calculated from all the data in Table III and to total lactate production $(r=+0.94)$, but this calculation is greatly influenced by the extremely high values in patient

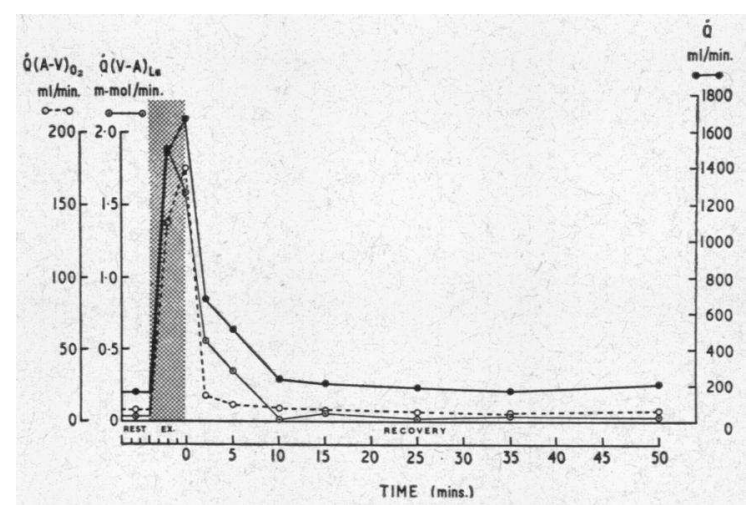

FIG. 2. $\dot{Q}, \dot{Q}(\mathrm{~A}-\mathrm{V}) \mathrm{O}_{2}$, AND $\dot{Q}(\mathrm{~V}-\mathrm{A}) \mathrm{LA}$ IN THE LOWER LIMB BEFORE, DURING, AND AFTER EXERCISE IN PATIENT H.L.C. (OCCLUSION OF SUPERFICIAL FEMORAL ARTERY).

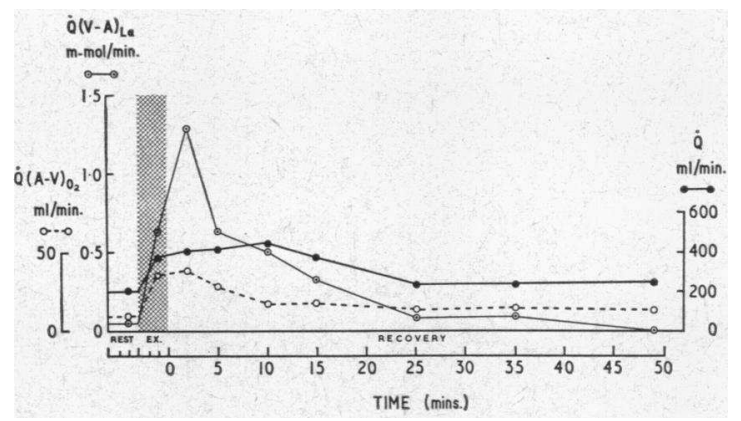

FIG. 3. $\dot{Q}, \dot{Q}(\mathrm{~A}-\mathrm{V}) \mathrm{O}_{2}$, AND $\dot{Q}(\mathrm{~V}-\mathrm{A}) \mathrm{LA}$ IN THE LOWER LIMB BEFORE, DURING, AND AFTER EXERCISE IN PATIENT J.MC. (OCCLUSION OF COMMON ILIAC ARTERY).

J.R. A more reliable correlation coefficient may be calculated from the data excluding patient J.R. The local oxygen debt then appears more closely related to excess lactate production $(r=+0.77)$ than to total lactate production $(\mathrm{r}=+0.64)$.

Pyruvate release. The mean arterial concentration of pyruvate at rest was 0.039 mmole per L (SD 0.015, $\mathrm{n}=10$ ), and in venous blood, 0.049 mmole per L (SD 0.013). There was a small negative arteriovenous difference (average 0.010 mmole per $L$ ) in all but one subject, but this was not significant. On exercise the arteriovenous difference became consistently negative, and there was an increased washout of pyruvate from the limb, which declined rapidly in the recovery period. Only in subjects J.R., H.L., and E.J. were appreciable quantities of pyruvate released from the limb after 4 minutes of the recovery period. Although systemic concentration of pyruvate always rose during exercise, frequently reaching

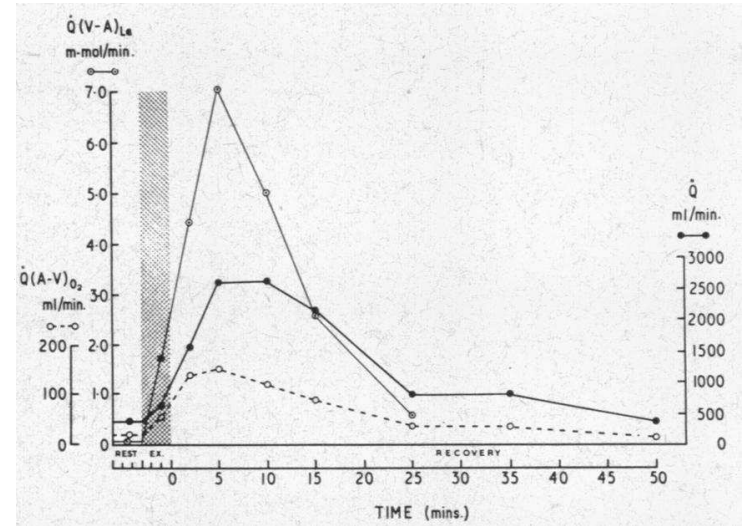

FIG. 4. $\dot{Q}, \dot{Q}(A-V) O_{2}$, AND $\dot{Q}(V-A) L A$ IN THE LOWER LIMB BEFORE, DURING, AND AFTER EXERCISE IN PATIENT J.R. (OCCLUSION OF COMMON ILIAC ARTERY). 


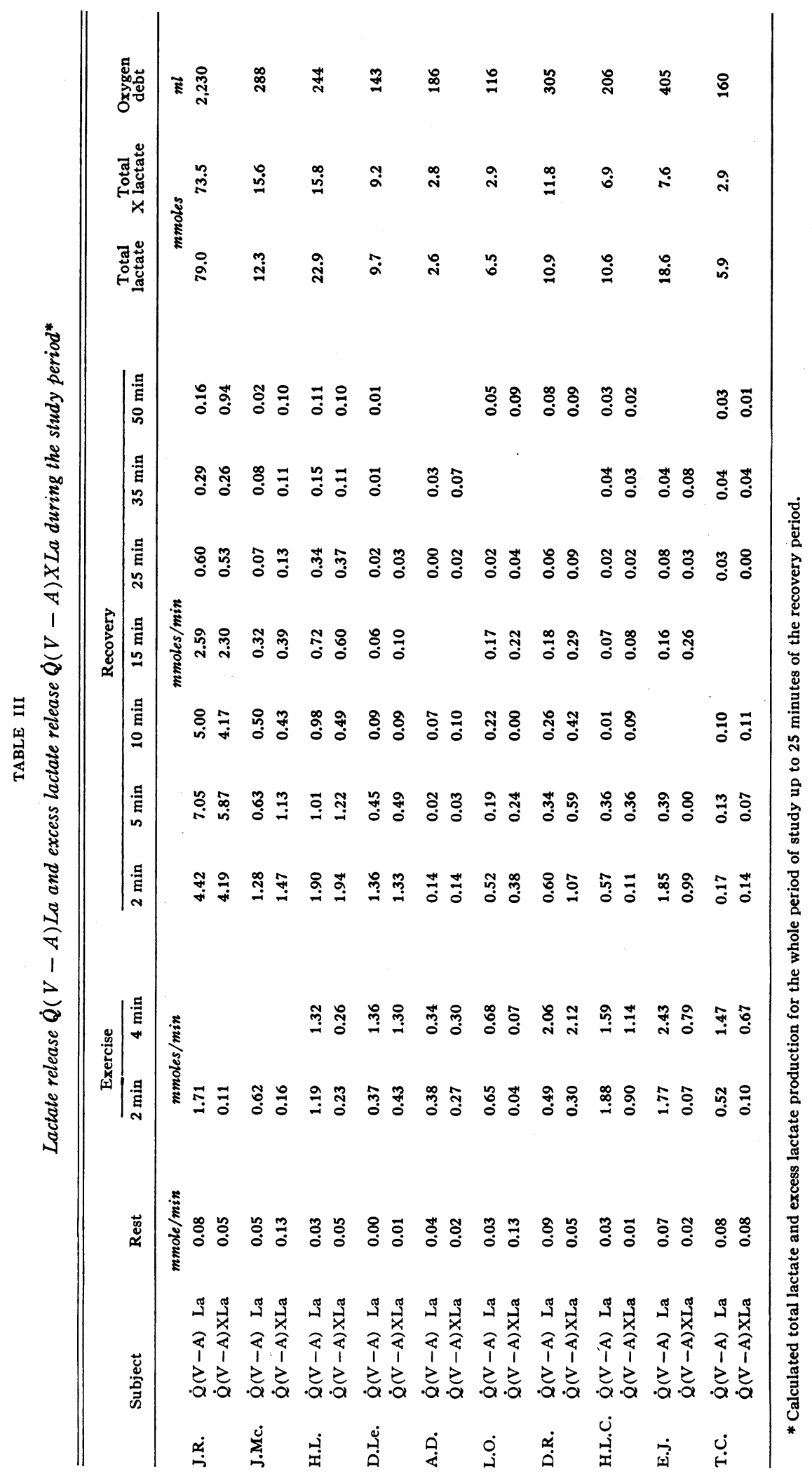


TABLE IV

Arterial and venous lactate-pyruvate ratios at rest, on exercise, and in the recovery period

\begin{tabular}{|c|c|c|c|c|c|c|c|c|c|c|c|}
\hline & & \multirow{3}{*}{$\begin{array}{l}\text { Rest } \\
20.0 \\
17.4\end{array}$} & \multicolumn{2}{|c|}{ Exercise } & \multicolumn{7}{|c|}{ Recovery } \\
\hline \multicolumn{2}{|c|}{ Subject } & & \multirow{2}{*}{$\begin{array}{l}2 \mathrm{~min} \\
24.0 \\
23.1\end{array}$} & \multirow[t]{2}{*}{$4 \mathrm{~min}$} & \multirow{2}{*}{$\begin{array}{c}2 \mathrm{~min} \\
28.8 \\
46.9\end{array}$} & \multirow{2}{*}{$\begin{array}{c}5 \mathrm{~min} \\
20.4 \\
32.3\end{array}$} & \multirow{2}{*}{$\begin{array}{l}10 \mathrm{~min} \\
18.7 \\
27\end{array}$} & \multirow{2}{*}{$\begin{array}{c}15 \mathrm{~min} \\
17.3 \\
23.5\end{array}$} & \multirow{2}{*}{$\begin{array}{c}25 \mathrm{~min} \\
15.3 \\
20.1\end{array}$} & \multirow{2}{*}{$\begin{array}{c}35 \mathrm{~min} \\
15.9 \\
16.2\end{array}$} & \multirow{2}{*}{$\begin{array}{c}50 \mathrm{~min} \\
14.7 \\
18.8\end{array}$} \\
\hline J.R. & $\mathbf{A}$ & & & & & & & & & & \\
\hline J.Mc. & $\mathbf{A}$ & $\begin{array}{l}28.6 \\
16.6\end{array}$ & $\begin{array}{l}18.1 \\
16.1\end{array}$ & & $\begin{array}{l}19.7 \\
44.1\end{array}$ & $\begin{array}{l}15.6 \\
26.5\end{array}$ & $\begin{array}{l}12.5 \\
16.4\end{array}$ & $\begin{array}{l}10.1 \\
16.0\end{array}$ & $\begin{array}{r}9.6 \\
14.2\end{array}$ & $\begin{array}{r}8.7 \\
13.0\end{array}$ & $\begin{array}{r}7.4 \\
10.4\end{array}$ \\
\hline H.L. & $\mathbf{A}$ & $\begin{array}{l}11.4 \\
13.2\end{array}$ & $\begin{array}{l}13.4 \\
14.8\end{array}$ & $\begin{array}{l}23.1 \\
25.0\end{array}$ & $\begin{array}{l}19.8 \\
43.9\end{array}$ & $\begin{array}{l}14.1 \\
21.9\end{array}$ & $\begin{array}{l}14.5 \\
18.5\end{array}$ & $\begin{array}{l}14.3 \\
21.7\end{array}$ & $\begin{array}{l}11.0 \\
17.3\end{array}$ & $\begin{array}{l}10.3 \\
13.5\end{array}$ & $\begin{array}{r}7.8 \\
11.8\end{array}$ \\
\hline D.Le. & $\begin{array}{l}\mathbf{A} \\
\mathbf{V}\end{array}$ & $\begin{array}{l}16.5 \\
14.8\end{array}$ & $\begin{array}{l}17.2 \\
27.9\end{array}$ & $\begin{array}{l}24.7 \\
31.9\end{array}$ & $\begin{array}{l}22.4 \\
35.7\end{array}$ & $\begin{array}{l}16.3 \\
26.6\end{array}$ & $\begin{array}{l}15.4 \\
21.8\end{array}$ & $\begin{array}{r}13.8 \\
9.3\end{array}$ & $\begin{array}{l}12.4 \\
18.4\end{array}$ & $\begin{array}{l}15.1 \\
15.5\end{array}$ & $\begin{array}{l}11.7 \\
12.4\end{array}$ \\
\hline A.D. & $\mathbf{A}$ & $\begin{array}{l}19.2 \\
22.4\end{array}$ & $\begin{array}{l}14.2 \\
17.8\end{array}$ & $\begin{array}{l}12.6 \\
18.2\end{array}$ & $\begin{array}{l}13.0 \\
13.1\end{array}$ & $\begin{array}{l}13.0 \\
14.0\end{array}$ & $\begin{array}{l}12.6 \\
15.9\end{array}$ & & $\begin{array}{l}15.1 \\
16.6\end{array}$ & $\begin{array}{l}13.1 \\
19.5\end{array}$ & \\
\hline L.O. & $\begin{array}{l}\mathbf{A} \\
\mathbf{V}\end{array}$ & $\begin{array}{l}25.3 \\
19.1\end{array}$ & $\begin{array}{l}21.3 \\
20.8\end{array}$ & $\begin{array}{l}22.9 \\
22.2\end{array}$ & $\begin{array}{l}13.5 \\
21.9\end{array}$ & $\begin{array}{l}14.5 \\
15.8\end{array}$ & $\begin{array}{l}16.5 \\
16.5\end{array}$ & $\begin{array}{l}16.0 \\
18.0\end{array}$ & $\begin{array}{l}15.3 \\
16.8\end{array}$ & & $\begin{array}{l}11.5 \\
15.6\end{array}$ \\
\hline D.R. & $\stackrel{\mathbf{A}}{\mathbf{V}}$ & $\begin{array}{l}18.5 \\
20.8\end{array}$ & $\begin{array}{l}19.1 \\
21.6\end{array}$ & $\begin{array}{l}20.5 \\
32.4\end{array}$ & $\begin{array}{l}15.7 \\
27.0\end{array}$ & $\begin{array}{l}13.7 \\
23.8\end{array}$ & $\begin{array}{l}13.8 \\
24.6\end{array}$ & $\begin{array}{l}12.9 \\
20.4\end{array}$ & $\begin{array}{l}16.4 \\
19.5\end{array}$ & & $\begin{array}{l}14.1 \\
20.6\end{array}$ \\
\hline H.L.C. & $\mathbf{A}$ & $\begin{array}{l}11.4 \\
12.3\end{array}$ & $\begin{array}{l}26.6 \\
33.3\end{array}$ & $\begin{array}{l}26.8 \\
29.4\end{array}$ & $\begin{array}{l}16.6 \\
17.6\end{array}$ & $\begin{array}{l}13.3 \\
17.6\end{array}$ & $\begin{array}{l}12.2 \\
17.1\end{array}$ & $\begin{array}{l}11.4 \\
15.1\end{array}$ & $\begin{array}{l}11.4 \\
12.4\end{array}$ & $\begin{array}{l}13.0 \\
16.1\end{array}$ & $\begin{array}{l}11.1 \\
12.5\end{array}$ \\
\hline E.J. & $\stackrel{\mathbf{A}}{\mathbf{V}}$ & $\begin{array}{l}16.8 \\
16.9\end{array}$ & $\begin{array}{l}17.3 \\
17.6\end{array}$ & $\begin{array}{l}23.8 \\
26.4\end{array}$ & $\begin{array}{l}12.3 \\
14.7\end{array}$ & $\begin{array}{l}11.6 \\
11.6\end{array}$ & & $\begin{array}{l}10.3 \\
16.8\end{array}$ & $\begin{array}{l}10.6 \\
11.5\end{array}$ & $\begin{array}{r}9.0 \\
13.7\end{array}$ & \\
\hline T.C. & $\stackrel{\mathbf{A}}{\mathbf{V}}$ & $\begin{array}{l}14.3 \\
20.7\end{array}$ & $\begin{array}{l}17.5 \\
18.7\end{array}$ & $\begin{array}{l}17.9 \\
21.9\end{array}$ & $\begin{array}{l}14.4 \\
12.3\end{array}$ & $\begin{array}{l}13.7 \\
21.5\end{array}$ & $\begin{array}{l}12.3 \\
16.6\end{array}$ & $\begin{array}{l}10.0 \\
14.5\end{array}$ & $\begin{array}{l}11.2 \\
10.9\end{array}$ & $\begin{array}{l}7.4 \\
9.6\end{array}$ & $\begin{array}{r}9.4 \\
10.0\end{array}$ \\
\hline
\end{tabular}

peak concentration in the early recovery period, the net release of pyruvate by the limb was frequently small.

Not infrequently the arteriovenous difference of pyruvate concentration became positive in the recovery period, suggesting an uptake of pyruvate by the recovering limb. The small number of observations limits statistical analysis, but in several patients (J.Mc., D.Le., A.D., D.R., and H.L.C.) the positive arteriovenous difference at some time exceeded twice the standard deviation (0.004) from the mean of the duplicate pyruvate estimations. In addition, in subjects J.Mc., D.Le., and D.R. the positive arteriovenous difference was observed over at least four sequential measurements, which is further evidence of true pyruvate uptake. This uptake usually occurred late in the recovery period when blood flow was steady and near resting levels; the quantities of pyruvate consumed were, therefore, extremely small in most cases.

Lactate-pyruvate ratio. In all subjects the restiny lactate-pyruvate ratio, both venous and arterial, was greater than that observed at some stage of the recovery period (Table IV) with the exception of the venous ratio in H.L.C. During exercise the ratio increased in eight subjects in venous blood and in seven subjects in arterial blood.

\section{Discussion}

Blood flow. It has previously been shown that occlusive arterial disease results in the reduction of peak blood flow through the limb during exercise and a prolongation of hyperemia into the recovery period (8). This is in agreement with earlier plethysmographic observations on reactive and postexercise hyperemia in normal subjects and patients with major artery obstruction (1719). In this study, the pattern of blood flow response varied from normal as seen in patient T.C. through varying degrees of reduced peak flow and prolonged hyperemia. Three subjects showed an increase in blood flow on passing from the period of activity to that of recovery. Two of these patients had common iliac artery obstruction, and one had occlusion of the common femoral artery at its origin. This flow pattern resembles that sometimes seen in the calf in the presence of proximal arterial disease in the lower limb (17). Similarly, hyperemia in the foot may be shown to follow that in the calf in the presence of obstruction of major limb arteries $(20,21)$. Whereas in the normal limb the main artery acts as a supply line with a low internal resistance, in the presence of occlusive arterial disease the resistance of the collateral vessels may limit arterial inflow. When inflow is limited and perfusion 
pressure reduced as beyond a common iliac artery obstruction, blood flow to the thigh and calf may not rise until the flow requirements of the more proximal regions have been fulfilled. In addition, there is evidence that arteries with reduced intraluminal pressure may be compressed by contracting skeletal muscle (22).

Lactate and excess lactate production and oxygen consumption. Although the measurement of external iliac venous blood flow does not account for total limb perfusion, the flow measurements are appropriate to the arteriovenous differences measured. The limitations imposed upon studies of regional metabolism by techniques that involve the measurement of arteriovenous differences have been analyzed by Zierler (23). Arteriovenous differences can only be equated with tissue metabolism when blood flow is constant and known and may only be used if arterial concentration and tissue uptake of the metabolite are also constant. In this study, blood flow is known and appears to have changed rapidly only in the first minute of exercise or recovery, as might be expected from the results of other workers (24-26), and measurements in these periods have been avoided. Whereas the calculated total quantity of lactate leaving the limb during the entire period of observation should be an accurate reflection of total lactate production, the apparent rate of production is likely to be distorted. In ischemic regions of the exercising limb volume blood flow is inappropriate to the mass of metabolizing tissue, and the capillary supply will be sparse. The transit time from cell to capillary will therefore be greatly increased. This phenomenon in addition to the delayed hyperemia in distal parts of the ischemic limb may partially explain the apparently prolonged lactate production by some subjects. It is, however, apparent that increased oxygen consumption was continued into the recovery period in a similar manner to the delayed washout or release of lactate. This observation suggests that oxygen lack was still present at that time unless there existed a considerable tissue oxygen store that had been depleted during exercise, and therefore lactate formation might reasonably be expected to continue. Lactate production occurs for a brief period into the recovery state to restore the content of adenosine triphosphate and creatine phosphate in muscle by further glycolysis.
In addition, in the absence of an adequate oxygen supply, the conversion of pyruvate to lactate may release a further supply of DPN required in the tricarboxylic acid cycle. As oxygen consumption by the limb returned to near resting levels, it was noted that lactate production was in a similar state. Excess lactate accounted for the majority of lactate produced in the limb in those patients with the most severe limitation of arterial inflow; this is in keeping with the biological concept of excess lactate as is the positive correlation between total excess lactate and local oxygen debt.

Controversy exists concerning the ability of skeletal muscle to resynthesize glycogen from lactate. Peters and Van Slyke (27) doubt whether skeletal muscle is capable of handling lactate at all. Harris, Bateman, and Gloster (7) demonstrated uptake of lactate by resting skeletal muscle during leg exercise, and under certain circumstances, skeletal muscle does appear to be capable of using lactate as a fuel. Thus, in the eviscerated rabbit, Drury, Wick, and Morita (28) demonstrated that muscle oxidized large amounts of lactate. This achievement was attributed to the high tissue concentrations present in the preparation, lactate replacing glucose as tissue fuel. Other workers have failed to show synthesis of glycogen from isotopic lactate by perfused muscle unless insulin and glucose were administered simultaneously (29). In the present study, the failure of the limbs to take up lactate in the later recovery period, when the blood flow and oxygen consumption of the limb had returned to normal but while the lactate concentration in arterial blood was still elevated, suggests that there is little metabolism of lactate by the limb musculature, although some degree of glycogen synthesis cannot be excluded.

Pyruvate production and the lactate-pyruvate ratio. In this study the resting lactate-pyruvate ratio, in both arterial and venous blood, was with one exception always higher than in the late recovery period. The explanation of the high ratio in the present study is to be found in the low resting concentration of pyruvate. Gloster and Harris (15) have demonstrated that the enzymatic method used here gives significantly lower readings than the phenylhydrazine method of Friedemann and Haugen (30), which was the technique most frequently used by the earlier investigators. Slight variations in pyruvate concentration, there- 
fore, result in large changes in lactate-pyruvate ratio. Delay in denaturation of blood results in loss of pyruvate $(31,32)$, but this error was avoided, and technical errors do not explain the systematic finding of a lower lactate-pyruvate ratio in the recovery period than in the pre-exercise period. It is pertinent to consider some of the resting blood pyruvate determinations, enzymatically determined, that have appeared in the literature in recent years. Landon, Fawcett, and Wynn (33) found a mean value of 0.05 mmole per $\mathrm{L}$ and Gloster and Harris (15) a mean value of 0.055 mmole per L. Two other groups of investigators found concentrations of 0.08 to 0.09 mmole per $L(34,35)$, but in both cases the subjects were postabsorptive and ambulatory, and the results of this study indicate a prolonged elevation of pyruvate levels after even mild degrees of exercise. Krasnow, Neill, Messer, and Gorlin (36) found a wide range of lactate-pyruvate ratios in arterial blood among a group of six resting normal subjects; the ratio varied from $3: 1$ to $13: 1$. In the present study, the average resting lactate-pyruvate ratio was $18: 1$. The observation that the lactate-pyruvate ratio is not at its lowest in the resting and fasting state suggests that it is either a less direct reflection of the reduction oxygenation potential than previously supposed, or that this potential is improved by a short period of light exercise. The latter possibility is worthy of consideration, since the circulatory and respiratory status of a subject is frequently more stable after a short period of light exercise than in the pre-exercising resting phase (37). It is possible that the prolonged period of rest and fasting for several hours, often overnight, was responsible for the low pyruvate concentrations. Finally, the degree of exercise by the patients was extremely light in this study, and the elevated blood pyruvate concentrations at 50 minutes after exercise emphasize the necessity to define carefully what is meant by the resting state for each study.

\section{Summary}

The external iliac venous blood flow was measured in nine patients with occlusive arterial disease and one with a normal lower limb vasculature. Changes in venous return during and after exercise have been monitored together with arteriovenous differences in oxygen, lactate, and pyruvate concentrations across the limb. The following conclusions were reached:

1. High peak blood flows during exercise with rapid return to resting values after exercise were seen in the normal subjects and patients with superficial femoral artery obstruction. Delayed hyperemia with peak flow in the recovery period was observed among subjects with more proximal arterial block.

2. Oxygen consumption and lactate release were continued long into the recovery period in patients with delayed hyperemia. This finding could be partly explained by a delayed hyperemia in distal parts of the limb, but probably represents some continuing anoxic state.

3. Total excess lactate accounted for a greater part of total lactate production in the patients with severe reduction of blood flow than in those with relatively high peak blood flow. There was a positive correlation between local oxygen debt and excess lactate production.

4. Blood flow returned to resting values before the arterial lactate concentration, and there was no evidence of lactate uptake by the limb.

5. Pyruvate release by the limb was slight, and there was occasionally evidence of pyruvate uptake by the limb in the recovery period.

6. The lactate-pyruvate ratio in both arterial and regional venous blood was usually higher in the pre-exercise period than that at some stage of the recovery period.

\section{Acknowledgments}

We wish to express thanks to Dr. J. P. Shillingford for his advice and encouragement and to Miss Jean Powell for drawing the diagrams.

\section{References}

1. Fletcher, W. M., and F. G. Hopkins. Lactic acid in amphibian muscle. J. Physiol. (Lond.) 1907, 35, 247.

2. Meyerhoff, O. Uber die Energieumwandlungen im Muskel 2. Pflügers Arch. ges. Physiol. 1920, 182, 232.

3. Hill, A. V., C. N. H. Long, and H. Lupton. Muscular exercise, lactic acid, and the supply and utilization of oxygen. Proc. roy. Soc. B 1924, 97, 84.

4. Himwich, H. E., V. D. Koskoff, and L. H. Nahum. Studies in carbohydrate metabolism. 1. A glucoselactic acid cycle involving muscle and liver. J. biol. Chem. 1929, 85, 571.

5. Donald, K. W., J. Gloster, E. A. Harris, J. Reeves, and $P$. Harris. The production of lactic acid dur- 
ing exercise in normal subjects and patients with rheumatic heart disease. Amer. Heart J. 1961, 62, 494.

6. Carlson, L. A., and B. Pernow. Studies on the peripheral circulation and metabolism in man. 1. Oxygen utilization and lactate-pyruvate formation in the legs at rest and during exercise in healthy subjects. Acta physiol. scand. 1961, 52, 328.

7. Harris, P., M. Bateman, and J. Gloster. The regional metabolism of lactate and pyruvate during exercise in patients with rheumatic heart disease. Clin. Sci. 1962, 23, 545.

8. Pentecost, B. L. The effect of exercise on the external iliac vein blood flow and local oxygen consumption in normal subjects, and in those with occlusive arterial disease. Clin. Sci. 1964, 27, 437.

9. Huckabee, W. E. Relationships of pyruvate and lactate during anaerobic metabolism. 1. Effects of infusion of pyruvate or glucose and of hyperventilation. J. clin. Invest. 1958, 37, 244.

10. Seldinger, S. I. Catheter replacement of the needle in percutaneous arteriography. A new technique. Acta radiol. (Stockh.) 1953, 39, 368.

11. Shillingford, J., T. Bruce, and I. Gabe. The measurement of segmental venous flow by an indicator dilution method. Brit. Heart J. 1962, 24, 157.

12. Kountz, S. L., W. J. Dempster, and J. P. Shillingford. Application of a constant indicator dilution method to the measurement of local venous flow. Circulat. Res. 1964, 14, 377.

13. Pentecost, B. L. M. D. Thesis, University of London, 1965.

14. Pentecost, B. L., D. W. Irving, and J. P. Shillingford. The effects of posture on blood flow in the inferior vena cava. Clin. Sci. 1963, 24, 149.

15. Gloster, J. A., and P. Harris. Observations on an enzyme method for the estimation of pyruvate in blood. Clin. chim. Acta 1962, 7, 206.

16. Huckabee, W. E. Relationship of pyruvate and lactate during anaerobic metabolism. IV. Local tissue components of total body $\mathrm{O}_{2}$-debt. Amer. J. Physiol. 1959, 196, 253.

17. Shepard, J. T. The blood flow through the calf after exercise in subjects with arteriosclerosis and claudication. Clin. Sci. 1950, 9, 49.

18. Gaskell, P. The rate of blood flow in the foot and calf before and after reconstruction by arterial grafting of an occluded main artery to the lower limb. Clin. Sci. 1956, 15, 259.

19. Hillestad, L. K. The peripheral blood flow in intermittant claudication. V. Plethysmographic studies. The significance of the calf blood flow at rest and in response to timed arrest of the circulation. Acta med. scand. 1963, 174, 23.

20. Winsor, T., C. Hyman, and J. H. Payne. Exercise and limb circulation in health and disease. Arch. Surg. (Lond.) 1959, 78, 184.

21. Allwood, M. J. Redistribution of blood flow in limbs with obstruction of a main artery. Clin. Sci. 1962, 22, 279.
22. Walder, D. N. A technique for investigating the blood supply of muscle during exercise. Brit. med. J. 1958, 1, 255.

23. Zierler, K. L. Theory of the use of arteriovenous concentration differences for measuring metabolism in steady and non-steady states. J. clin. Invest. 1961, 40, 2111.

24. Kramer, K., T. Obal, and W. Quensel. Untersuchungen über den Muskelstoffwechsel des Warmblüters. III. Die Sauerstoffaufnahme des Muskels während rhythmischer Tärigkeit. Pflügers Arch. ges. Physiol. 1939, 241, 717.

25. Donald, K. W., P. N. Wormald, S. H. Taylor, and J. M. Bishop. Changes in the oxygen content of femoral venous blood and leg blood flow during leg exercise in relation to cardiac output response. Clin. Sci. 1957, 16, 567.

26. Ganz, V., A. Hlavová, A. Froněk, J. Linhart, and I. Přerovský. Measurement of blood flow in the femoral artery in man at rest and during exercise by local thermodilution. Circulation 1964, 30, 86.

27. Peters, J. P., and D. D. Van Slyke. Quantitative Clinical Chemistry Interpretations. London, Balliere, Tindall \& Cox, 1946, vol. 1.

28. Drury, D. R., A. N. Wick, and T. N. Morita. Metabolism of lactic acid in extra hepatic tissues. Amer. J. Physiol. 1955, 180, 345.

29. Omachi, A., and N. Lifson. Metabolism of isotopic lactate by the isolated perfused dog gastrocnemius. Amer. J. Physiol. 1956, 185, 35.

30. Friedemann, T. E., and G. E. Haugen. Pyruvic acid. II. The determination of keto acids in blood and urine. J. biol. Chem. 1943, 147, 415.

31. Bueding, E., and H. Wortis. The stabilization and determination of pyruvic acid in the blood. J. biol. Chem. 1940, 133, 585.

32. Huckabee, W. E. Control of concentration gradients of pyruvate and lactate across cell membranes in blood. J. appl. Physiol. 1956, 9, 163.

33. Landon, J., J. K. Fawcett, and V. Wynn. Blood pyruvate concentration measured by a specific method in control subjects. J. clin. Path. 1962, 15, 579.

34. Cobb, L. A., and W. P. Johnson. Hemodynamic relationships of anaerobic metabolism and plasma free fatty acids during prolonged, strenuous exercise in trained and untrained subjects. $\mathrm{J}$. clin. Invest. 1963, 42, 800.

35. Naimark, A., N. L. Jones, and S. Lal. The effect of hypoxia on gas exchange and arterial lactate and pyruvate concentration during moderate exercise in man. Clin. Sci. 1965, 28, 1.

36. Krasnow, N., W. A. Neill, J. V. Messer, and R. Gorlin. Myocardial lactate and pyruvate metabolism. J. clin. Invest. 1962, 41, 2075.

37. Taylor, S. H., G. R. Sutherland, D. C. S. Hutchison, B. S. L. Kidd, P. C. Robertson, B. M. Kennelly, and $\mathrm{K}$. W. Donald. The effects of intravenous guanethidine on the systemic and pulmonary circulation in man. Amer. Heart. J. 1962, 63, 239. 